. Review Article

\title{
Exchange rate and Industrial Output within an SVAR Framework: Evidence from Nigeria
}

\author{
Ayinde, R. A. \\ ayinderamat@gmail.com \\ Nile University Of Nigeria
}

\begin{abstract}
Absract:
The Nigerian exchange rate has gone through several reforms. Thus, this study seeks to also establish, the manner with which variations in the exchange rates influence industrial production.It focuses essentially on the impact of a shock to the exchange rate on industrial production in Nigeria. The study employs the use of the SVAR (Structural Vector Autoregressive) model with the assumption of Cholesky decomposition as an identification scheme for four variables in the following order: exchange rate, industrial output, broad money supply, and price level.It is found that for the period under study, industrial output plays no role in explaining the fluctuations in the real exchange rate in the short run. Similarly, results show that shock to the real exchange rate plays no role in explaining the fluctuations in industrial output in the short run. However, by the end of a second-year period, the industrial output takes $23 \%$ of the fluctuations in the real exchange rate and the real exchange rate explains about $17 \%$ of the fluctuation in industrial output. As an extension, analyses show that shock to inflation and money supply have minimal influence on industrial output.It is recommended that a concentration on real factors such as savings rate, infrastructural facilities, political stability, and security can provide relatively more influence on industrial production in Nigeria.This study has contributed to knowledge through the analysis of data to identify the impact of a shock to the exchange rate on industrial production in Nigeria.
\end{abstract}

Keywords: Industrial Production, Exchange Rate, SVAR, Money Supply and Inflation

\section{Introduction:}

The exchange rate is a macroeconomic variable used for policymaking and can be stated in its nominal form or its real form. The nominal exchange rate measures the relative price of two currencies while the real exchange rate measures the relative price of two goods, that is, tradeable (export and imports) to non-tradeable goods. The nominal exchange rate (NER) and the real exchange rate (RER) relate basically through the nominal exchange rate as changes in the NER can influence the value of RER. For instance, an appreciation of NER will result in the appreciation of RER. The exchange rate is an important monetary policy tool. It serves the role of a connecting price for different countries which influences the value of exports and imports, usually to promote exports and discourage imports. It serves to allocate real resources between the tradeable and non-tradeable sectors because the exchange rate affects the decisions of producers, consumers, and investors in the two sectors, that is, the domestic and external 
sectors.Due to the importance of exchange rates, governments take an active role in the determination of its price. Since the postindependence, the Nigerian exchange rate has undergone several changes. The period 1959 to June 1986, the Nigerian exchange rate policy aligned with the International Monetary Fund (IMF) fixed exchange rate system. During this period up till thelate 1970s, the Nigerian exchange policy objective was to equilibrate the balance of payments and preserve the value of the external reserves. Hence, the exchange rate moved with the oil price thus encouraging more imports and capital flight because of a sharp increase in oil prices, the currency was overvalued. Throughout the 1970s except 1976 and 1977, the nominal exchange rate appreciated every year. Thus discouraging exports and promoting imports led to balance of payment problems and depletion of external reserves. Also, importation of inputs for industries was encouraged resulting in a boom of importsubstituting industries and assists the manufacturing sector as inputs were sourced cheaply. However, the agricultural sector was neglected and output sufferedas annual production of cocoa, rubber, cotton, and groundnut fell by $42,29,65$, and $64 \%$ between 1970 and 1985(Samuel, 2017).Under the structural adjustment program (SAP) of 1986, the floating exchange rate system was implemented such thatthe exchange rate became market-determined. Specifically, the floating exchange rate system was implemented from June 1986 - to date. This system started with a dual foreign exchange rate system, the first and second-tier foreign exchange market (SFEM). The first tier system operated a fixed exchange rate which applies to the official international transactionswhile the second tier system had a marketdetermined rate and applies to the rest of the transactions. The objectives of the SFEM framework seek to achieve short-term foreign exchange rate stability and long-term balance of payments equilibrium. The SFEM achieved its aim through a downward adjustment of the first tier exchange rate to achieve a gradual depreciation of the naira until the two rates converge which occurred in 1987 at the rate of \$3.74 to \$1 (David, Dikko, and Gulumbe; 2016). In 1987, the SFEM metamorphosed into a single FEM and in 1988 changed to Autonomous Foreign Exchange Market (AFEM) and then transformed to Inter-bank Foreign Exchange Market (IFEM) in 1989. The Central Bank of Nigeria $(\mathrm{CBN})$ continued to monitor developments in the foreign exchange markets to achieve the appropriate price for the foreign exchange rate. By 1990, the Retail Dutch Auction System (RDAS) was introduced, although first introduced in 1987 and subsequently Wholesale Dutch Auction System (WDAS) in 2006.The DAS involves the selling of foreign exchange currencies to authorized dealers by the central bank after the optimal bidding price has been determined by the central bank, then the authorized dealers sell it to the end-users. The major difference between RDAS and WDAS is that with RDAS authorized dealers sell directly to the end-user while for wholesale DAS, the dealers can bid more than what the end-users requested, with the rest being sold in the foreign exchange market. DAS was introduced as an authorized dealer of the exchange rate activities to avoid outrageously high bid rates which result in the depreciation of the currency. The RDAS was first introduced in 1987, reintroduced in 2002 withdrawn in 2006, reintroduced in January 2009 withdrawn in July 2009, and finally reintroduced in February 2013, and withdrawn in October 2015. On the other hand, the WDAS was first introduced in February 2006 and reintroduced in July 2009 (CBN, 2016). 
RDAS was introduced in 2006 to close the widening gap between the official and parallel markets which it achieved by narrowing premium and restoring confidence in the foreign exchange market system. It was however dropped in 2006 for the WDAS system to consolidate on the achievements of RDAS and liberalize the foreign exchange market. WDAS further reduced the demand pressure for the foreign exchange rate which resulted in its stability. In 2008, however, due to the currency of the global financial crisis, there was an increased outflow of the currency hence sudden depreciation of the currency which the WDAS system could not curtail hence CBN reintroduced RDAS in Jan 2009. RDAS is to ease the increased demand for foreign exchange but failed as demand pressure persisted and depreciation of the currency was the order of the day, hence, the return to WDAS by July 2009. In February 2013, again RDAS was introduced to ease demand pressures. It was however dropped in October 2015 because of the widening between the interbank rates and official rate. Since October 2015, the CBN has moved all demand for foreign exchange to the interbank market. The Nigerian exchange rate has gone through several reforms hence imperative to investigate the impact of exchange rate fluctuations on economic performance in Nigeria. This study seeks to analyze the relationship between the Nigerian exchange rates and industrial output using Structural Vector Autoregressive (SVAR) model. The study uses each of the nominal and real exchange rates against the industrial output to establish the relationship. Using two models, this study seeks to also establish, the manner with which variations in the exchange rates explain industrial production. The rest of the paper is structured as follows: Section 2 discusses the relevant theory and literature to the study, while in section 3, the methodology to the study is described, section 4 analyses the results, and section 5 concludes.

\section{Literature Review: \\ 2.1 Theoretical Review:}

The Mundell-Fleming-Dornbusch framework is the dominant model for the analysis of international monetary policy, which is an extension of Mundell-Fleming's work on exchange rate policy for small economies. It was developed in Dornbusch 1976 and was published after the collapse of the Bretton woods system of the fixed exchange rate. This theory was designed to give explanations for two major happenings after the Second World War. First, the nominal exchange rate was fluctuating far more than the fundamental drivers of the economy such as aggregate demand, supply, and monetary policy. That is, small changes in fundamentals result in large changes in the nominal exchange rate. Second, nominal exchange rate volatility translated into real exchange rate volatility. Given the definition of the real exchange rate as the relative price of 2 goods, that is, tradeable and non-tradeable, it is expected that the real exchange rate to remain relatively stable.Assumptions of the model include that amoney-demand relationship exists, the home economy cannot affect the rest of the world due to its size, prices are sticky so they assumed fixed and arbitrage across different currencies exists. Starting with the interest rate, the home interest rate is defined as

$$
\mathrm{i}_{\mathrm{t}+1}=\log \left(1+\mathrm{I}_{\mathrm{t}+1}\right)
$$

Where $\mathrm{i}$ is the log home interest rate. The home interest rate to the foreign interest rate and the exchange rate is called the uncovered interest rate parity and is defined as

$$
\begin{aligned}
& \mathrm{i}_{\mathrm{t}+1} \\
& =\mathrm{i}^{*}+\mathrm{e}_{\mathrm{t}+1} \\
& -\mathrm{e}_{\mathrm{t}}
\end{aligned}
$$

$\mathrm{i}^{*}$ is the foreign interest rate is assumed to be fixed and not influenced by the economic activities of the home country. $e$ is the $\log$ of 
the exchange rate. Equation 1 representing uncovered interest rate parity implies that perfect arbitrage exists whereby investors move their investment around to ensure this equality.

The second equation in the model is the money demand equation defined as

$$
\begin{aligned}
& \mathrm{m}_{\mathrm{t}}-\mathrm{p}_{\mathrm{t}} \\
& =-\omega \mathrm{i}_{\mathrm{t}+1} \\
& +\varphi \mathrm{y}_{\mathrm{t}}
\end{aligned}
$$

Real money balances are a function of interest rate and output. Negative relations exist between real money balances and interest rate and a positive relationship exists between real money balances and output.

The third equation is the real exchange rate expressed in its log form

$$
\begin{aligned}
& \mathrm{q} \\
& =\mathrm{e}+\mathrm{p}^{*} \\
& -\mathrm{p}
\end{aligned}
$$

Where $\mathrm{q}$ is the real exchange rate, $\mathrm{p}^{*}$ is the foreign price, $p$ is the local price. If purchasing power parity holds then $\mathrm{q}=1$.

The fourth equation is the aggregate demand described as follows

$$
y_{t}^{d}=\bar{y}+\delta\left(e_{t}+p^{*}-p_{t}-\right.
$$

That is, the aggregate demand is equal to equilibrium, $\bar{y}$, or the natural rate of output but is moved around by the deviations of the real exchange rate from its equilibrium. $\bar{q}$ is the equilibrium exchange rate. If $\mathrm{q}=\overline{\mathrm{q}}$ then $\mathrm{y}_{\mathrm{t}}^{\mathrm{d}}=$ $\overline{\mathrm{y}}$.

The fifth equation represents the supply side of the model which is given by the expectation augmented Phillips curve

$$
\begin{aligned}
\mathrm{p}_{\mathrm{t}+1}-\mathrm{p}_{\mathrm{t}}= & \gamma\left(\mathrm{y}_{\mathrm{t}}^{\mathrm{d}}-\overline{\mathrm{y}}\right) \\
& +\left(\tilde{\mathrm{p}}_{\mathrm{t}+1}\right. \\
& \left.-\tilde{\mathrm{p}}_{\mathrm{t}}\right)
\end{aligned}
$$

The Phillips curve shows the amount of produce by firms in the economy. $\tilde{p}_{\mathrm{t}}=\mathrm{e}_{\mathrm{t}}+\mathrm{p}_{\mathrm{t}}^{*}-\overline{\mathrm{q}}_{\mathrm{t}}$ is the price that will prevail if $\mathrm{y}_{\mathrm{t}}^{\mathrm{d}}=\overline{\mathrm{y}}$. So that change in $\tilde{\mathrm{p}}_{\mathrm{t}}$ is given by

$$
\begin{aligned}
& \tilde{\mathrm{p}}_{\mathrm{t}+1}-\tilde{\mathrm{p}}_{\mathrm{t}}=\left(\mathrm{e}_{\mathrm{t}+1}+\mathrm{p}_{\mathrm{t}+1}^{*}-\overline{\mathrm{q}}_{\mathrm{t}+1}\right)-\left(\mathrm{e}_{\mathrm{t}}+\right. \\
& \left.\mathrm{p}_{\mathrm{t}}^{*}-\overline{\mathrm{q}}_{\mathrm{t}}\right) .
\end{aligned}
$$

After a series of substitutions using the four equations into the fifth, the final equation is obtained as

$$
\mathrm{p}_{\mathrm{t}+1}-\mathrm{p}_{\mathrm{t}}=\gamma\left(\mathrm{y}_{\mathrm{t}}^{\mathrm{d}}-\overline{\mathrm{y}}\right)+\mathrm{e}_{\mathrm{t}+1}-\mathrm{e}_{\mathrm{t}}
$$

What is the effect of raising the long-run level of money?

Here the concentration is on the impact of change in the long-run level of money on output as well as exchange rate which are the focus of this study. Thus assume the long-run level of money supply increases from $\overline{\mathrm{m}}$ to $\overline{\mathrm{m}}^{\prime}$, use the money demand equation which relates real money balances with interest rate and output, that is,

$$
\mathrm{m}_{\mathrm{t}}-\mathrm{p}_{\mathrm{t}}=-\omega \mathrm{i}_{\mathrm{t}+1}+\varphi \mathrm{y}_{\mathrm{t}}
$$

From the output equation, the impact on output can be seen, that is

$$
\mathrm{y}_{\mathrm{t}}^{\mathrm{d}}=\overline{\mathrm{y}}+\delta\left(\mathrm{e}_{\mathrm{t}}+\mathrm{p}^{*}-\mathrm{p}_{\mathrm{t}}-\overline{\mathrm{q}}\right)
$$

Hence output will rise by $\delta\left(\overline{\mathrm{m}}^{\prime}-\overline{\mathrm{m}}\right)$. This is because $p_{t}$ is sticky and do not change, $\bar{q}$ does not change, hence e is the only item that can change, and in the long run, nominal exchange rate moves proportionally with money such that $e_{t}$ is replaced with $\left(\bar{m}^{\prime}-\bar{m}\right)$ which is the increment in aggregate demand in the short run.In the long-run, the exchange rate rises proportionally with the rise in the money stock, simply because the price will increase proportionately with the money stock at home, for which it is offset by a movement in the exchange rate which implies that the real exchange rate stays at its long-run level and doesn't change.In conclusion, this model helps to explain the reasons why the exchange rate is so volatile, that a permanent increase in a country's money supply will result in a rise in the exchange rate (a long-run depreciation of the country's currency) because prices do not 
adjust quickly, the goods market adjust slowly but the financial market adjustsimmediately. In the same vein, a permanent decrease in the country's money supply will result in a longrun appreciation of the currency.

\subsection{Empirical Review}

This section reviewsrecent literature about the relationship between the exchange rate as a monetary policy tool, industrial production, and economic growth broadly. In Chuku 2009, the effect of monetary policy innovations (shocks) on output and prices is examined for the case of Nigeria using the Structural Vector Autoregression Model. 3 monetary policy instruments are used, that is, broad money (M2), Minimum Rediscount Rate (MRR), and the real effective exchange rate (REER). It found that a positive shock in the real exchange rate increases real output with the positive effects commencing in the fourth quarter and petering out in the eighth quarter. In a similar study in Ogun 2016, the relative strength of different measures of the Nigerian real exchange rate at influencing its economic growth is assessed. Using an unweighted multilateral index and 3 geometrical measures of the exchange rate were used to test the causal relations with the GDP using a time frame 1962-2011. Regardless of the form of the data series, level, or order of integration, it is found that only interest rate granger causes the real exchange rate. No causal relationship is observed between the exchange rate and economic growth. In Akinlo and Lawal (2015), the impact of exchange rate on industrial production in Nigeria is examined using quarterly data over the period 1986 2010 in a VEC Model. It is found that the exchange rate has no impact on industrial production in the short run but a positive effect exists in the long run. That is a depreciation of the currency results in an increase in industrial production in the long run.In Low and Chan
(2017), the dynamic relationship among macroeconomic variables such as GDP, foreign exchange rate, inflation rate, and interest rate for Malaysia is examined using analysis of VECM (Vector ErrorCorrection Modelling). It finds a positive relationship between GDP and Forex hence depreciation of the currency relates to a rise in the GDP. It also finds a unidirectional causal relationship between exchange rate and economic growth arising from the exchange rate. In Ozcelebi and Yildirim (2011), the relationship between exchange rates and output is examined within the SVAR Blanchard-Quah framework for Turkey with its major trading partners: Germany and Russia. The results obtained from the impulse response functions andforecast error variance decompositions are analyzed for the two SVAR models. It is found that a positive response of industrial production to nominal exchange rate shock, however, this positive response is temporary. Precisely, it is seen that industrial production jumps to its long-run value immediately after the shock and such increases do not last long.

In Kohler, Manalo, and Perera (2014) the temporary and permanent effect of movements of the real exchange rate in Australia on its economic activity and inflation is examined. Using SVAR with data ranging from 1985Q1 to 2013Q2 and with the following variables employed, that is, terms of trade, trimmed mean inflation, the cash rate, Australia GDP, USA GDP, and the real exchange rate. It is found that a temporary 10 percent depreciation in the exchange rate increases the level of GDP temporarily by a small amount of 0.25 to 0.5 percent for one to two years. A permanent 10 percent real depreciation is also estimated to have a positive relationship increasing the level of GDP by around 1 percent after 2 to 3 years. Erjavec, Cota, and Jaksic (2012) examined changes in the real exchange rate in Croatia arising from real and nominal sources. Data employed ranged from January 1998 to 
March 2011 employing the SVAR model. The variables employed in the model are the real effective exchange rate (supply shock), aggregate output level proxy by industrial output (demand shock), and the price level

(nominal shock). Using variance decomposition and impulse response function for its analysis, the study finds that a major part (89 percent) of the volatility in the real exchange rate growth is attributed to demand shock, 9.7 percent attributed to supply shock, and 1.1 percent attributed to the nominal shock. Thus, it implies that the real exchange rate volatility is mainly driven by real shocks, hence the real exchange rate is seen as a shock absorber that stabilizes the Croatia economy. With regards to the impulse response function which measures the effect of one-time structural shock, it is found that a positive real aggregate demand shock leads to a permanent depreciation of the real exchange with an initial depreciation of almost 0.7 percent after a month and remains permanent. On the other hand, a positive nominal shock on the real exchange rate result in appreciation within two months after the shock and also the effect remains permanent.

\subsection{Data And Methodology:}

This study employs quarterly data spanning from 1981Q1 to 2017Q4 using five variables, that is, the nominal exchange rate (NER), industrial output (INDOUT), Broad money supply (M2), inflation rate (INF), and real effective exchange rate (REER). The nominal exchange rate measures the relative price of two currencies, that is, the naira against the US dollar. It is the price of a US dollar in terms of units of naira. The inclusion of the nominal exchange rate as a variable for analysis is standard given the research topic. Data is obtained from the Central Bank of Nigeria statistical bulletin 2017 and is described in figure 1 below.

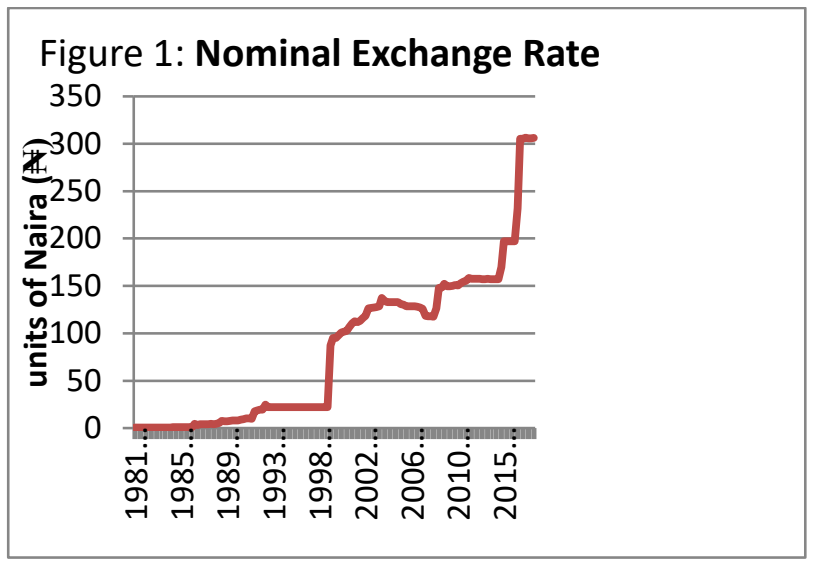

The second variable for analysis is the broad money supply (M2), which is one of the monetary policy tools used by the Central Bank for control of economic activities in Nigeria.Data is obtained from the Central Bank of Nigeria statistical bulletin 2017 and is described in figure 2 below.

Figure 2: Broad Money Supply (M2)

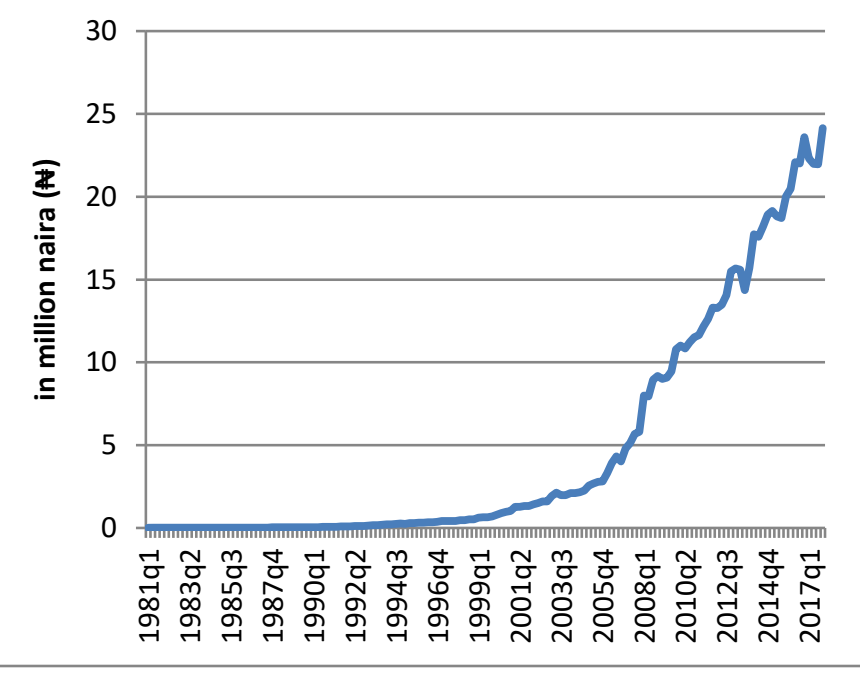

Industrial output is the third variable for analysis which is obtained from the world development index (WDI) 2017. Industrial output is a core variable in the model given the research topic. It is described in figure 3 below 


\section{Figure 3: Industrial Output}

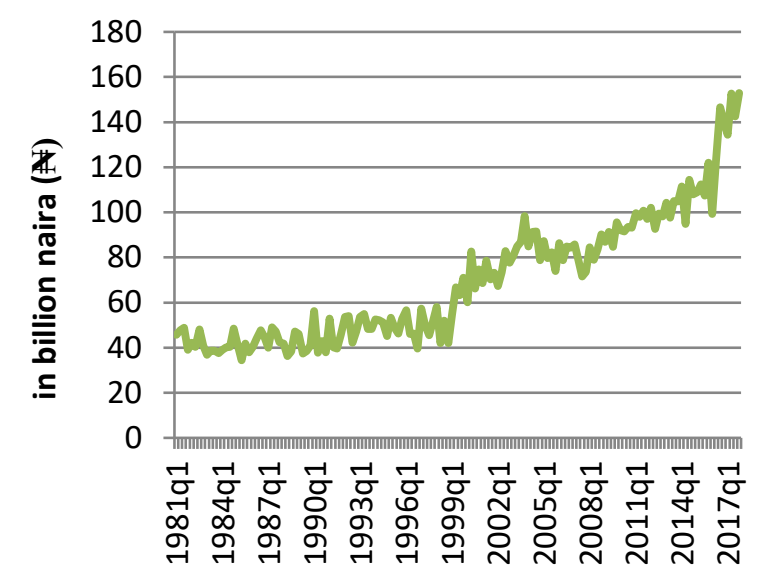

The fourth variable for analysis is the inflation rate which is a target of monetary policy and also the price level in Nigeria is influenced by the level of exchange rate hence its inclusion in the foregoing analysis is inevitable. Data on inflation is obtained from the Central Bank Statistical Bulletin 2017 and it is described below.

\section{Figure 4: Inflation rate}

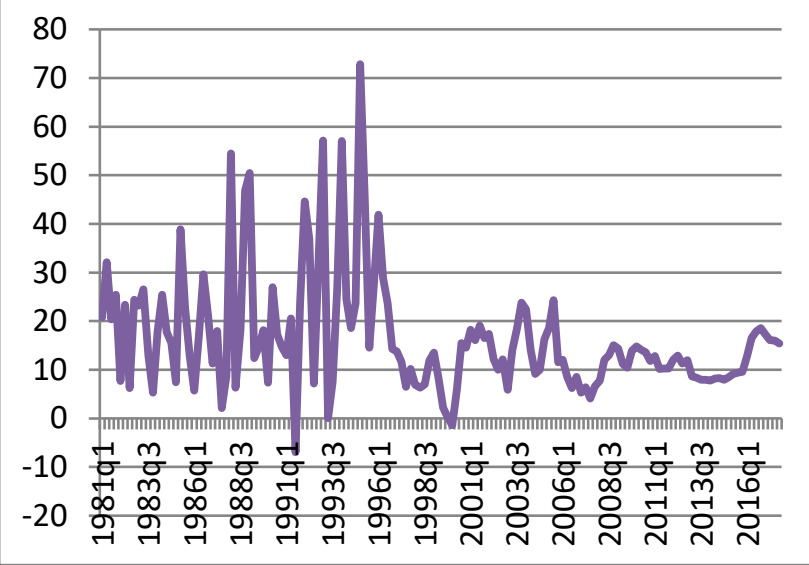

The real exchange rate measures the relative price of two countries' consumption baskets. The inclusion of the real exchange rate as a variable for analysis is standard given the research topic. The Real Effective Exchange Rate of the World Development Index 2017 is made use of as the real exchange rate and it is described in figure 5 below.

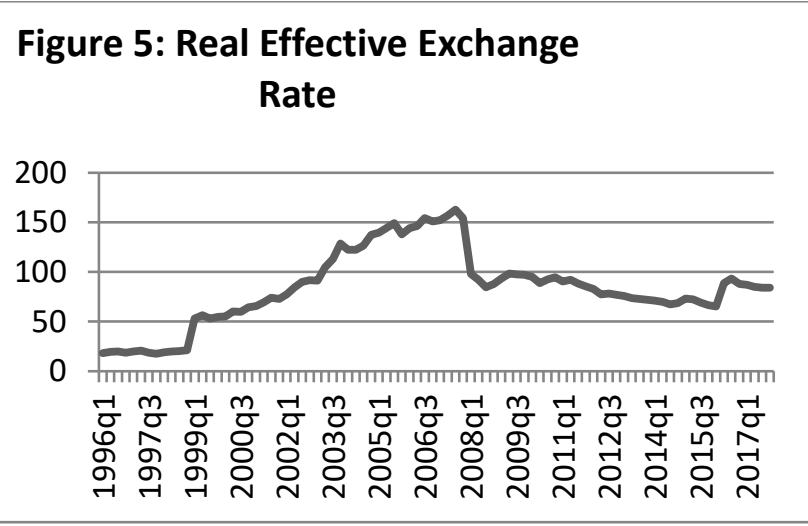

\subsection{Research Methodology:}

This study employs a Structural Vector Autoregression (SVAR) model to estimate the effect of exchange rate policy on industrial output for the Nigerian economy. SVAR is a straightforward method to analyze macroeconomic relationships with few variables and less restrictive assumptions. This study estimates two SVAR models with the vector of the endogenous variable specified as $\mathrm{X}_{\mathrm{t}}^{\prime}=\left[\begin{array}{llll}\Delta \mathrm{q}_{\mathrm{t}} & \Delta \mathrm{y}_{\mathrm{t}} & \Delta \mathrm{r}_{\mathrm{t}} & \Delta \mathrm{p}_{\mathrm{t}}\end{array}\right]$, where $\Delta$ denotes the difference operator and the variables employed are industrial output $\left(\mathrm{y}_{\mathrm{t}}\right)$, broad money supply $\left(r_{t}\right)$, inflation rate $\left(p_{t}\right)$ and $\left(q_{t}\right)$ representing the nominal exchange rate for the first model and the real exchange rate for the second model. All variables are in their natural logarithm form. It is assumed that the economy can be represented by the following structural form:

$$
\mathrm{AX}_{\mathrm{t}}=\mathrm{BX}_{\mathrm{t}-1}+\varepsilon_{\mathrm{t}} \quad \text { for } \mathrm{t}=1, \ldots, \mathrm{T}
$$

$\varepsilon_{\mathrm{t}}$ is a $4 \mathrm{x} 1$ vector of unobservable zero-mean white noise process which implies that they are serially uncorrelated and independent of each other such that $\mathrm{E}\left(\varepsilon_{\mathrm{t}} \varepsilon_{\mathrm{t}+\mathrm{s}}^{\prime}\right)=0$ for all $\mathrm{s} \neq 0$ and $\mathrm{E}\left(\varepsilon_{\mathrm{t}} \varepsilon_{\mathrm{t}}^{\prime}\right)=\mathrm{C}$. $\mathrm{A}$ is a $4 \mathrm{x} 4$ non-singular matrix normalized to have ones on the diagonal. It summarizes the relationship that exists between the endogenous variables. $\mathrm{B}$ is a $4 \mathrm{x} 4$ matrix showing how variables are affected by their lags and the lags of other variables. $\mathrm{C}$ is a diagonal matrix whose off-diagonal elements are zero and diagonal elements are ones representing the variance. The structural VAR model cannot be estimated with OLS because 
they violate one important assumption that the regressor cannot be correlated with the error term, as a result, OLS will produce inconsistent estimates of the parameter, impulse responses, etc. This problem is generated through the A matrix, hence to recover consistent estimates then the reduced-form VAR is estimated. So that the model becomes

$$
\begin{gathered}
A^{-1} A X_{t}=A^{-1} B X_{t-1}+A^{-1} \varepsilon_{t} \\
X_{t}=F X_{t-1}+u_{t} \\
\text { Where } E\left(u_{t} u_{t}^{\prime}\right)=\Omega u_{t} \sim N(0, \Omega) \\
\text { So that } F=A^{-1} B, u_{t}=A^{-1} \varepsilon_{t}
\end{gathered}
$$

The structural disturbances and the reducedform residuals are related by $\varepsilon_{\mathrm{t}}=\mathrm{Au}_{\mathrm{t}}$. Since we are interested in the structural shocks obtained through $\varepsilon_{t}=A_{t}$, a major challenge is to pin down the A matrix. A simple two-step maximum likelihood estimation procedure can be employed to recover the structural parameter (see Lawson and Rees, 2008). First, estimate $\Omega$ from the reduced form model, then estimate A and $\mathrm{C}$ matrices can be obtained. Although the focus is the A matrix, the first step of estimating $\Omega$ brings the challenge as

$$
\begin{aligned}
\Omega=\mathrm{E}\left[\mathrm{u}_{\mathrm{t}} \mathrm{u}_{\mathrm{t}}^{\prime}\right] & =\mathrm{E}\left[\mathrm{A}^{-1} \varepsilon_{\mathrm{t}}\left(\mathrm{A}^{-1} \varepsilon_{\mathrm{t}}\right)^{\prime}\right] \\
& =\mathrm{E}\left[\mathrm{A}^{-1} \varepsilon_{\mathrm{t}} \varepsilon_{\mathrm{t}}^{\prime}\left(\mathrm{A}^{-1}\right)^{\prime}\right] \\
& =\mathrm{E}\left[\mathrm{A}^{-1}\left(\mathrm{~A}^{-1}\right)^{\prime}\right]
\end{aligned}
$$

The A matrix includes 16 unknowns while $\Omega$ use to the A matrix includes only 10 equations because it is a symmetric matrix. Thus making the system of equations not identified. There are several identification schemes, a popular method, followed here, is to orthogonalize the reduced form disturbances by Cholesky decomposition. This simply means placing restrictions on the A matrix such that it becomes a lower triangular matrix hence the LHS of the model becomes

$$
\left[\begin{array}{cccc}
1 & 0 & 0 & 0 \\
\mathrm{a}_{21} & 1 & 0 & 0 \\
\mathrm{a}_{31} & \mathrm{a}_{32} & 1 & 0 \\
\mathrm{a}_{41} & \mathrm{a}_{42} & \mathrm{a}_{43} & 1
\end{array}\right]\left[\begin{array}{c}
\Delta \mathrm{q}_{\mathrm{t}} \\
\Delta \mathrm{y}_{\mathrm{t}} \\
\Delta \mathrm{r}_{\mathrm{t}} \\
\Delta \mathrm{p}_{\mathrm{t}}
\end{array}\right] \equiv \mathrm{AX}_{\mathrm{t}}
$$

Thus the equation for the exchange rate is given

$$
\Delta \mathrm{q}_{\mathrm{t}}=\mathrm{BX}_{\mathrm{t}-1}+\varepsilon_{\mathrm{qt}}
$$

This implies that the exchange rate is not contemporaneously affected by any of the variables except only with a lag. The exchange rate in Nigeria is assumed to be affected contemporaneously by foreign factors e.g. the price of crude oil

The equation for industrial output is given as

$$
\Delta \mathrm{y}_{\mathrm{t}}=-\mathrm{a}_{21} \Delta \mathrm{q}_{\mathrm{t}}+\mathrm{BX}_{\mathrm{t}-1}+\varepsilon_{\mathrm{yt}}
$$

This implies that industrial output is contemporaneously affected by the only exchange rate in the economy but not contemporaneously with broad money supply and the price level except with its lag. Here exchange rate is assumed to affect output contemporaneously because of the importdependent nature of the country for both raw materials and infrastructure used in production. The money supply equation is given as

$$
\Delta \mathrm{r}_{\mathrm{t}}=-\mathrm{a}_{31} \Delta \mathrm{q}_{\mathrm{t}}-\mathrm{a}_{32} \Delta \mathrm{y}_{\mathrm{t}}+\mathrm{BX}_{\mathrm{t}-1}+\varepsilon_{\mathrm{rt}}
$$

This implies that output and exchange rate influences money supply contemporaneously as discussed in section 2 of this study according to the MFD model. The price level inflation is given as

$$
\begin{gathered}
\Delta \mathrm{p}_{\mathrm{t}}=-\mathrm{a}_{41} \Delta \mathrm{q}_{\mathrm{t}}-\mathrm{a}_{42} \Delta \mathrm{y}_{\mathrm{t}}-\mathrm{a}_{43} \Delta \mathrm{r}_{\mathrm{t}}+\mathrm{BX}_{\mathrm{t}-1} \\
+\varepsilon_{\mathrm{pt}}
\end{gathered}
$$

The price level is contemporaneously affected by all the variables.

\subsection{Empirical Results:}

Given the nature of the data at hand, a time series data, unit root test is conducted to ensure stationarity of the data set with the result displayed in table 1 . The unit root test conducted shows that the variables nominal exchange rate (q), industrial output (y), and money supply ${ }^{\circledR}$ are all not stationary at a level for both the Augmented Dickey-Fuller (ADF) and Phillips Peron (PP) tests conducted but rather they found stationary at first difference. The only inflation rate is found stationary at level and this is quite obvious from the inflation graph displayed in section 3 above. As a result 
of the unit root test obtained, the first difference of all variables is used for analysis.

\begin{tabular}{|c|c|c|c|c|c|}
\hline \multicolumn{6}{|c|}{ Table 1 Unit Root Test } \\
\hline \multirow{2}{*}{$\begin{array}{l}\text { Variab } \\
\text { les }\end{array}$} & \multicolumn{2}{|c|}{ ADF Test } & \multicolumn{2}{|c|}{ PP Test } & \multirow{2}{*}{$\begin{array}{c}\text { Decisi } \\
\text { on }\end{array}$} \\
\hline & $\begin{array}{l}\mathrm{t}- \\
\text { statist } \\
\text { ic }\end{array}$ & $\begin{array}{l}\text { P- } \\
\text { valu } \\
\text { e }\end{array}$ & $\begin{array}{l}\mathrm{t}- \\
\text { statist } \\
\text { ic }\end{array}$ & $\begin{array}{l}\text { P- } \\
\text { valu } \\
\mathrm{e}\end{array}$ & \\
\hline$q^{n}$ & $\begin{array}{l}- \\
13.25 \\
08\end{array}$ & $\begin{array}{l}0.40 \\
25\end{array}$ & $\begin{array}{l}- \\
1.792 \\
9\end{array}$ & $\begin{array}{l}0.38 \\
29\end{array}$ & $\begin{array}{l}\text { Not } \\
\text { station } \\
\text { ary }\end{array}$ \\
\hline$q^{r}$ & $\begin{array}{l}- \\
.7922 \\
92\end{array}$ & $\begin{array}{l}0.38 \\
21\end{array}$ & $\begin{array}{l}- \\
1.792 \\
3\end{array}$ & $\begin{array}{l}0.38 \\
21\end{array}$ & $\begin{array}{l}\text { Not } \\
\text { station } \\
\text { ary }\end{array}$ \\
\hline $\mathrm{Y}$ & $\begin{array}{l}0.811 \\
9\end{array}$ & $\begin{array}{l}0.99 \\
40\end{array}$ & $\begin{array}{l}- \\
0.448 \\
1\end{array}$ & $\begin{array}{l}0.89 \\
65\end{array}$ & $\begin{array}{l}\text { Not } \\
\text { station } \\
\text { ary }\end{array}$ \\
\hline $\mathrm{R}$ & $\begin{array}{l}- \\
0.818 \\
0\end{array}$ & $\begin{array}{l}0.81 \\
07\end{array}$ & $\begin{array}{l}- \\
0.785 \\
9\end{array}$ & $\begin{array}{l}0.81 \\
98\end{array}$ & $\begin{array}{l}\text { Not } \\
\text { station } \\
\text { ary }\end{array}$ \\
\hline $\mathrm{P}$ & $\begin{array}{l}- \\
8.000 \\
1\end{array}$ & $\begin{array}{l}0.00 \\
00\end{array}$ & $\begin{array}{l}- \\
7.933 \\
9\end{array}$ & $\begin{array}{l}0.00 \\
00\end{array}$ & $\begin{array}{l}\text { Station } \\
\text { ary }\end{array}$ \\
\hline$\Delta q^{n}$ & $\begin{array}{l}- \\
13.25 \\
08\end{array}$ & $\begin{array}{l}0.00 \\
00\end{array}$ & $\begin{array}{l}- \\
13.24 \\
93\end{array}$ & $\begin{array}{l}0.00 \\
00\end{array}$ & $\begin{array}{l}\text { Station } \\
\text { ary }\end{array}$ \\
\hline$\Delta q^{r}$ & $\begin{array}{l}- \\
7.566 \\
0\end{array}$ & $\begin{array}{l}0.00 \\
00\end{array}$ & $\begin{array}{l}- \\
7.529 \\
6\end{array}$ & $\begin{array}{l}0.00 \\
00\end{array}$ & $\begin{array}{l}\text { Station } \\
\text { ary }\end{array}$ \\
\hline$\Delta \mathrm{y}$ & $\begin{array}{l}- \\
12.95 \\
57\end{array}$ & $\begin{array}{l}0.00 \\
00\end{array}$ & $\begin{array}{l}- \\
23.02 \\
51\end{array}$ & $\begin{array}{l}0.00 \\
00\end{array}$ & $\begin{array}{l}\text { Station } \\
\text { ary }\end{array}$ \\
\hline$\Delta \mathrm{r}$ & $\begin{array}{l}- \\
12.63 \\
95\end{array}$ & $\begin{array}{l}0.00 \\
00\end{array}$ & $\begin{array}{l}- \\
12.66 \\
61\end{array}$ & $\begin{array}{l}0.00 \\
00\end{array}$ & $\begin{array}{l}\text { Station } \\
\text { ary }\end{array}$ \\
\hline
\end{tabular}

To analyze the effect of exchange rate on industrial output, the focus of analysis is centered on the impulse response function and forecast error variance decomposition. Variance decomposition shows how much of the future uncertainty of one time series is as a result of future shocks by the other time series in the system. This proportion evolves such that a shock on a time series may not be very important in the short run but becomes very important in the long run.

\section{MODEL 1}

Table 2 reports the variance decomposition for the nominal exchange rate at selected horizons.

Table 2: Variance Decomposition for Nominal Exchange Rate

\begin{tabular}{|l|l|l|l|}
\hline Shocks & $\begin{array}{l}1 \\
\text { Quarter }\end{array}$ & 1 year & 2 years \\
\hline $\begin{array}{l}\text { Nominal } \\
\text { exchange } \\
\text { rate shock }\end{array}$ & 100.000 & 95.969 & 89.915 \\
\hline $\begin{array}{l}\text { Money } \\
\text { supply } \\
\text { shock }\end{array}$ & 0.000 & 1.472 & 1.054 \\
\hline $\begin{array}{l}\text { Output } \\
\text { shock }\end{array}$ & 0.000 & 1.236 & 4.246 \\
\hline $\begin{array}{l}\text { Price } \\
\text { shock }\end{array}$ & 0.000 & 1.323 & 4.784 \\
\hline
\end{tabular}

The results of the variance decomposition for nominal exchange rate show that shock to exchange rate plays the dominant role to explain the fluctuations in the nominal exchange rate and this dominant role continued till the end of the second year. Industrial output and price shock play no role in explaining the fluctuations in the nominal exchange rate in the contemporary however by the end of the second year period, it takes roughly $5 \%$ of the fluctuations. A much smaller proportion is due to the money supply shock. Thus none of the variables in the model is seen to explain the volatility of the nominal exchange rate. 
Table 3: Variance Decomposition for Industrial Output

\begin{tabular}{|l|l|l|l|}
\hline Shocks & 1 Quarter & 1 year & 2 years \\
\hline $\begin{array}{l}\text { Exchange } \\
\text { rate shock }\end{array}$ & 5.404 & 23.746 & 29.182 \\
\hline $\begin{array}{l}\text { Money } \\
\text { supply } \\
\text { shock }\end{array}$ & 0.796 & 1.622 & 1.891 \\
\hline $\begin{array}{l}\text { Output } \\
\text { shock }\end{array}$ & 93.800 & 74.019 & 66.820 \\
\hline Price shock & 0.000 & 0.614 & 2.107 \\
\hline
\end{tabular}

Table3 reveals the variance decomposition for industrial output which shows that in quarter 1 , much of the variation in the industrial output is caused by a shock to output itself, however as the period expands, the shock to exchange rate explains almost $30 \%$ of the fluctuation in industrial output. For price level and money supply, they take a negligible percentage in the fluctuation to industrial output even at 2 years. As a result, industrial output volatility is mainly driven by output itself but a shock to the nominal exchange rate takes a significant percentage. Thus the nominal exchange rate helps to explain the fluctuations in the money supply shock but not vice versa.

\section{Impulse response functions (responses to One Standard Deviation Shock)}

The impulse response function (irf) measures the impact of an upward unanticipated one-unit change in the impulse variable on the response variable over several periods. Here, the focus is on the response of nominal exchange rate and industrial output. Figure 5 reveals that a positive shock to the nominal exchange rate appreciates gradually for the entire period of 2 years plus 2 quarters. This implies that a positive shock to the nominal exchange rate will result in a gradual appreciation of the naira in the short and long run. The result is statistically significant for the entire period at a 95 percent confidence interval.

Figure 5: Response of Nominal Exchange rate to Nominal Exchange

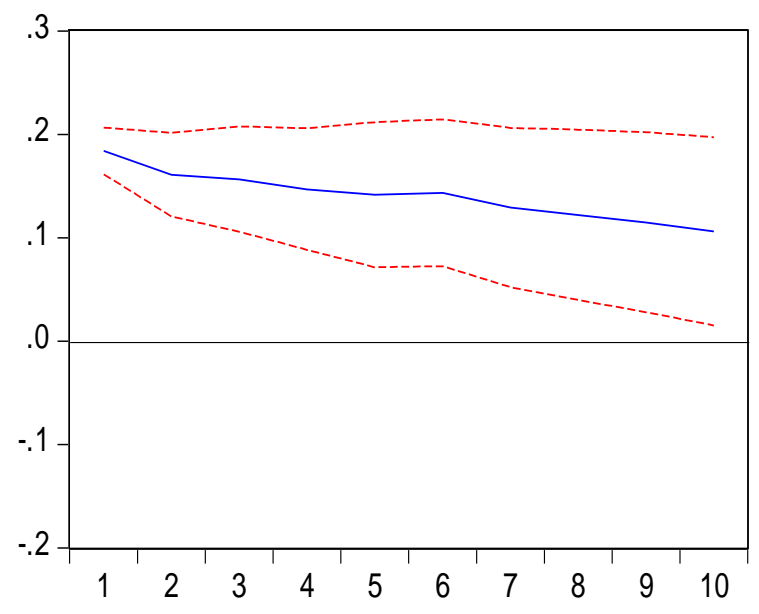

Concerning industrial output, Figure 6 reveals that a positive shock to industrial output has no effect on the nominal exchange rate until the fourth period where a fall (an appreciation) in the nominal exchange rate is observed of about -0.4 percent and falls continuously, although the result is significant statistically only from period 8. On the other hand, with regards response of industrial output to shock in the nominal exchange rate has an oscillatory pattern as seen in figure 7 . At the initial stage, a positive shock to the nominal exchange rate results in a rise in industrial output, and then by the next period resulted in a fall and then a rise. The result is statistically significant until period 6. Despite the oscillatory pattern, there is an overall downward trend to the effect of a positive shock to the exchange rate on industrial output. According to the MFD theory reviewed, a positive shock to aggregate output is expected to create demand for home goods and thus result in the appreciation of the currency although in this case, industrial output is the focus, the result obtained is consistent with theory. 
Figure 6 Response of Real Exchange rate to Industrial output shock

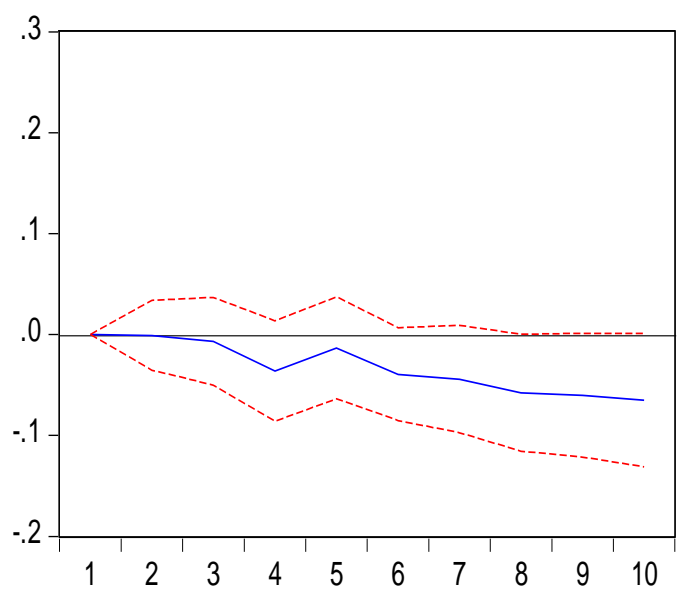

Figure 7 Response of Industrial Output to Nominal exchange rate shock

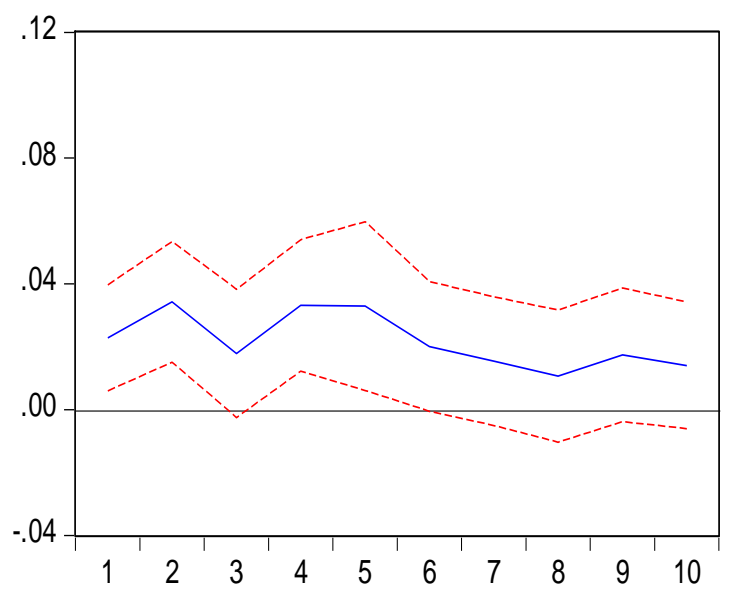

Figure 8 Response of Industrial Output to Industrial Output Shock

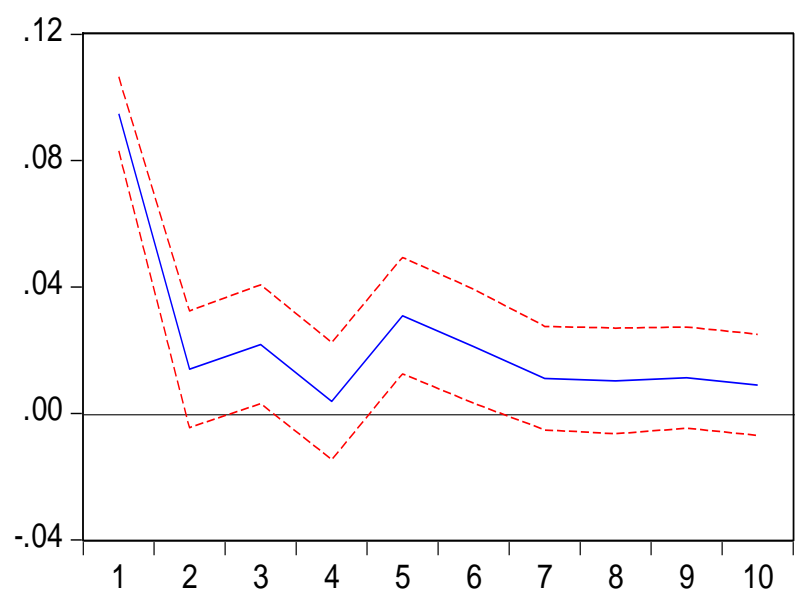

\section{Model 2}

Table 4: Variance Decomposition for Real Exchange Rate

\begin{tabular}{|l|l|l|l|}
\hline Shocks & 1 Quarter & 1 year & 2 years \\
\hline $\begin{array}{l}\text { Real exchange } \\
\text { rate shock }\end{array}$ & 100.000 & 80.4738 & 72.0582 \\
\hline $\begin{array}{l}\text { Money supply } \\
\text { shock }\end{array}$ & 0.000 & 0.5235 & 0.8460 \\
\hline Output shock & 0.000 & 16.1124 & 23.4463 \\
\hline Price shock & 0.000 & 2.8904 & 3.6496 \\
\hline
\end{tabular}

The results of the variance decomposition for real exchange rate is shown in table 4 and indicates that shock to real exchange rate plays the dominant role to explain the fluctuations in the real exchange rate and this dominant role continued till the end of the second year, although the proportion attributed to the real exchange rate reduced from 100 in quarter 1 to 72 by end of year 2 . Industrial output plays no role in explaining the fluctuations in the real exchange rate in the contemporary however by the end of the second year period, it takes $23 \%$ of the fluctuations. A negligible proportion is due to money supply shock and price shock. Thus it can be said that industrial output is seen to explain the volatility of the real exchange rate. Comparing results in table 2 and table 4, it can be concluded that while industrial output contributes to the volatility of the real exchange rate, no such relationship is observed between industrial output and nominal exchange rate.

Table 5: Variance Decomposition for Industrial Output

\begin{tabular}{|l|l|l|l|}
\hline Shocks & 1 Quarter & 1 year & 2 years \\
\hline $\begin{array}{l}\text { Real } \\
\text { exchange } \\
\text { rate shock }\end{array}$ & 0.0526 & 9.1934 & 17.0242 \\
\hline $\begin{array}{l}\text { Money } \\
\text { supply shock }\end{array}$ & 5.0223 & 7.1854 & 7.6027 \\
\hline Output shock & 94.9251 & 80.1205 & 70.8126 \\
\hline Price shock & 0.0000 & 3.5006 & 4.5606 \\
\hline
\end{tabular}


Table 5 reveals the variance decomposition for industrial output which shows that in quarter 1, much of the variation in the industrial output is caused by a shock to output itself, however as the period expands, the shock to real exchange rate explains almost $17 \%$ of the fluctuation in industrial output. For price level and money supply, they take a negligible percentage in the fluctuation to industrial output even at 2 years. As a result, industrial output volatility is mainly driven by output itself but the shock to the real exchange rate takes only a small percentage. Thus a comparison of results in table 3 and table 5 indicates the nominal exchange rateexplain significantly the fluctuations in the industrial output while no such relationship is concluded for industrial output and real exchange rate.

\section{Impulse response functions (responses to One Standard Deviation Shock)}

Figure 9 reveals that a positive shock to the real exchange rate appreciates and gradually converges to zero. This implies that a positive shock to the real exchange rate will result in an appreciation of the naira, although the result is statistically significant only in the first and second periods. Figure 10 reveals that a shock to industrial output has an immediate effect on real exchange with a negative effect in the first two periods. The value subsequently fluctuates around the zero lines. This is unlike what is observed with regards nominal exchange rate whereby a positive shock to industrial output has no immediate effect on the nominal exchange rate until the fourth period where a fall (an appreciation) in the nominal exchange rate is observed. Figure 11, reveals the response of industrial output to shock in the real exchange rate which has an immediate positive effect in the firsttwo periods and subsequently hovers around the zero lines. Figure 12 reveals the response of industrial output to shock in industrial output which shows that a sharply negative effect is experienced in the first two quarters and subsequently the value fluctuates sharply around the zero lines.

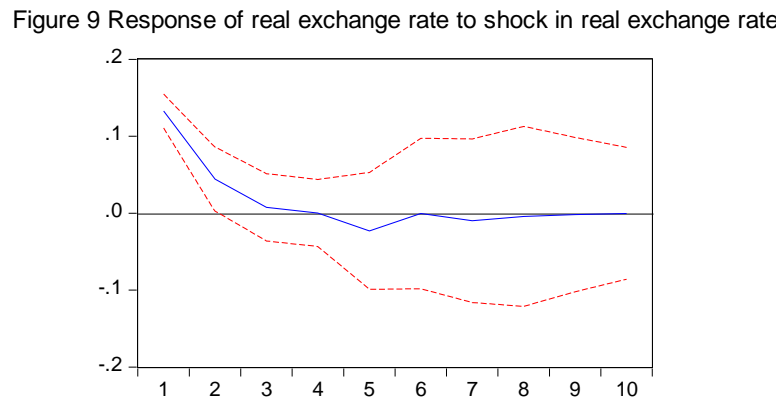

Figure 10 Response of real exchange rate to shock in industrial output

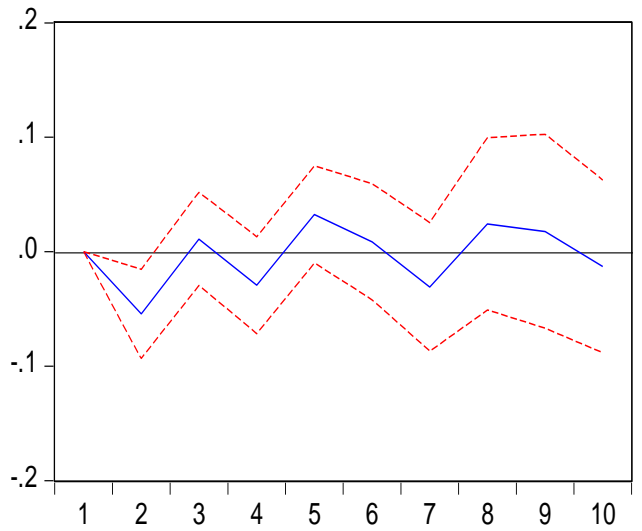

Figure 11 Response of industrial output to shock in real exchange rate

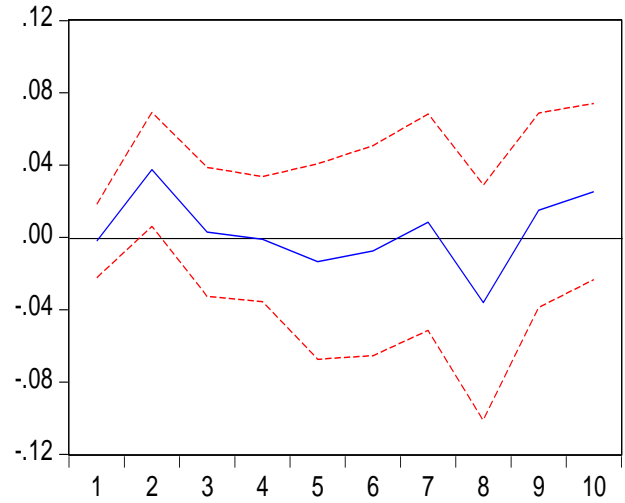

Figure 12 Response of industrial output to shock in industrial output

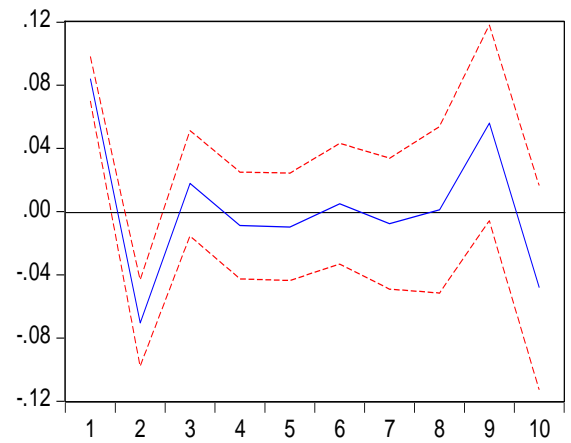




\subsection{Conclusion}

This study examines the relationship between exchange rate and industrial production in Nigeria using quarterly data spanning 1981Q1 to 2017Q4. It employs the Structural Vector Autoregression (SVAR) Model in its analysis. Two SVAR models are employed with the first focusing on the nominal exchange rate, industrial output, money supply, and inflation as the endogenous variables in the model. The second SVAR model has real exchange rate, industrial output, money supply, and inflation as its endogenous variables. The rationale behind employing two models lies in assessing the outcomes generated if any similarity is observed. The variance decomposition and impulse response functions are employed for analysis. From the analysis, it is observed that shock to industrial output explains only 5\% fluctuations in the nominal exchange rate and about $23 \%$ fluctuations in the real exchange rate by the end of the second year. Hence, it can be concluded that while industrial output contributes to the volatility of the real exchange rate, no such relationship is observed between industrial output and nominal exchange rate. Furthermore, it is observed that shock to nominal exchange rate explains only about $17 \%$ fluctuation in industrial output in 2 years. Thus shock to nominal exchange rate explains more of the variation in industrial output than real exchange rate does. The impulse response function graph indicates that the response of nominal exchange rate to shock in industrial output has no effect on nominal exchange rate until the $4^{\text {th }}$ period where a fall in the nominal exchange rate is observed of about -0.4 percent and falls continuously. Similarly, the response of the real exchange rate to shock in industrial output has an oscillatory pattern with an immediate fall of about -.05 percent at period 2 . Results observed for nominal exchange rate which confirms that an initial negative effect is seen then a negative effect and then a positive one and so on. The effect is seen to converge gradually towards zero by period 10. Similarly, the response of real exchange rate to shock in industrial output also has an oscillatory pattern with an initial negative effect which gradually converges towards zero by period 10 .

\section{References}

1. Akinlo, O. O., \& Lawal, Q. A. (2015). Impact of exchange rate on industrial production in Nigeria 1986-2010. International Business and Management, 10(1), 104-110.

2. Central Bank of Nigeria, CBN (2016). Foreign Exchange Rate, Education in Economics Series, Number 4, CBN Research Department.

3. Chuku, C. A. (2009). Measuring the effects of monetary policy innovations in Nigeria: A structural vector autoregressive (SVAR) approach. African Journal of Accounting, Economics, Finance, and Banking Research, 5(5).

4. David, R. O., Dikko, H. G., \&Gulumbe, S. U. (2016). Modeling volatility of the exchange rate of the Naira to major currencies. CBN Journal of Applied Statistics, 7(2), 159-187.

5. Erjavec, N., Cota, B., \&Jaksic, S. (2012). Sources of exchange rate fluctuations: Empirical evidence from Croatia. PrivrednaKretanjuaiEkonomskaPoliti ka, 22(132), 27.

6. Low, Y. W., \& Chan, T. H. (2017). Foreign Exchange Rate, Interest Rate, Inflation Rate, and Economic Growth in Malaysia. Global Business and Management Research, 9(4s), 110-127.

7. Kohler, M., Manalo, J., \&Perera, D. (2014). Exchange rate movements and economic activity. RBA Bulletin, March, 47-54. 
Adedoyin Ramat Ayind ${ }^{1}$ /An Econometric Analysis Of Entrepreneurship And Unemployment For Sub-Saharan Africa: 2006 -2016

8. Ozcelebi, O., \& Yildirim, N. (2011). Revisiting the relationship between exchange rates and output within the SVAR Blanchard-Quah framework: empirical evidence from Turkey, Germany, and Russia. Economic \& Business Review, 13(3).
9. Samuel, A. O. (2017). Problems and Prospects of Cocoa Production in Nigeria Economy: A Review. International Journal of Social Sciences, 11(2) 